\title{
Determination and sensory evaluation of soy flour-meat combinations in the production of meatballs
}

\section{O. M. Odiase, J .O. I gene, S.E. Evivie* and P.A. E babhamiegbebho}

Food Science and Technology Unit, Department of Animal Science, Faculty of Agriculture, University of Benin, PMB 1154, Benin city, NIGERIA

*Corresponding author. E-mail: smithyevivie@gmail.com

Received:O ctober 8, 2013; Revised received: N ovember 14, 2013; Accepted:D ecember 5, 2013

\begin{abstract}
The increasing cost of animal protein has necessitated the need to investigate the use of cheaper and nutritive alternatives in various food formulations. The study was carried out to determine the appropriate level of soy flour inclusion in meatball production. The soy meat balls were formulated to contain $0 \%, 10 \%, 15 \%, 20 \%$ and $25 \%$ of full-fat soy flour which was combined with beef and some condiments. Treatments were analyzed in triplicates in a randomized complete block design. A 7-point hedonic scale was used to evaluate the sensory characteristics (colour, taste, texture and overall acceptance) of the products using a semi-trained taste panel. Nutrient proximate composition values and production cost were also determined. Results showed that on the average, soy flour inclusion in meatballs increased cooking yield by reducing weight loss from $27.33 \%$ to $12.96 \%$. Meatballs with soy flour inclusions at $10 \%$ and $15 \%$ were most acceptable (very much liked). The $20 \%$ and $25 \%$ level of soy flour inclusion were moderately acceptable, thereby indicating acceptability up to $25 \%$ level of soy flour inclusion. Soy inclusion reduced production cost by N37.50 on the average at N5.00 per ball when compared with all meat products as well as, increasing the number of balls per mix from 64 balls (control) to an average number of 89.5 balls (soy meatball). It is recommended that further studies of the soy flour inclusion in meatballs production be carried out to ensure the availability of cheaper, nutritious and acceptable convenience food in the Nigerian market.
\end{abstract}

Keywords: Meatballs, Sensory evaluation, Soy flour-meat

\section{INTRODUCTION}

As the world population continues to grow, various governments are confronted with the serious challenge of meeting the complex food needs of societies faced with short supply of animal protein. Protein is one of the major nutrients in diets needed by the human body. Since soy bean is a rich and cheaper source of plant protein, increasing research into its production and utilization would ensure a steady avenue for providing the much needed cheap but balanced protein. This would meet the teething challenges of declining protein availability in the form of soy-based food; such as soy meat combination in the form of soy meatball (Iwe, 2003; Igene et al., 2012; Igene et al., 2006; Igene et al., 2002). One of the reasons animal proteins is costly is perhaps the high cost of animal feed which is more than $65 \%$ of the cost of production (Olomu, 2011). In view of the increased interest in soy-based foods such as soy-meat, there is need to strategise in defining the relationship between specific diet component such as soy protein and human health (WHF, 2004). This specifically relates to the mechanisms of beneficial cholesterol lowering and anti-carcinogenic effects of soy proteins and other soy components (Friedman and Brandon, 2001; Raji and Famurewa, 2008).
Soybean processing in Nigeria started with the processing of soybean into daddawa in the Southern Kaduna area of Kaduna State. As popularization of the crop as a source of human food progressed, Home Economics at the Ahmadu Bello University, Zaria documented the preparation of soy milk and soy flour. The timely preparation of soy flour was introduced when the use of composite flours became necessary following the ban on importation of wheat by the Babangida military administration into the processing of soy bean and later on, processors of soy flour or powder came along (Iwe, 2003). Soy protein used in the meat production is increasing because of their unique functional characteristics as meat extenders and functional ingredients. Meat extenders are defined as proteins which are non-meat proteins but are usually plant proteins. A wide variety of meat extenders are available for use in emulsion type sausages to improve consistency, emulsifying and water holding capacity (FAO, 1991). The main value of plant protein in comminuted meat products is to reduce formulation cost. They have the ability to improve viscosity, texture, firmness, moisture, overall yield, fat binding, emulsifying capacity, sensory properties and storage stability (Kinsella, 1979). The 
increasing use of soy proteins in meat product is also due to the availability and low cost of soybean relative to other extenders such as cotton, sunflower, wheat flour, sodium caseinate, egg protein and non-fat dry milk (Lecomte et al., 1993). They are also used in processing frankfurters, bologna, meat loaves, meatballs, meat patties, and luncheon meats (Igene et al., 2002).

Health benefits of soy in meat include prevention of heart diseases, cancer, high blood pressure, diabetes-related disease and many others. Soy bean oil is rich in fatty acids and devoid of cholesterol. It is an excellent source of calcium, iron, and vitamins such as niacin, thiamin and riboflavin. Soy contains all essential amino acid apart from methionine and tryptophan. These amino acids closely match those required for humans. (Russell, 2004; Sacks et al., 2006). Soy-meat may also help with menopause symptoms and osteoporosis. Soy contains an impressive array of phytochemicals (biologically active components derived from plants (Sacks et al 2006), which are beneficial to human nutrition. The proximate composition, cost analysis and sensory characteristics of soy meatballs among other important parameters are yet to be evaluated

The increased level of urbanization in Nigeria has informed the need to develop more convenience products using meat and although some studies have investigated the development of various forms of meatballs, studies on the inclusion of soy was scarce (Igene et al., 2006; Igene et al., 2012). The objectives of this study are therefore to determine the best level of soy flour inclusion appropriate for meatball using beef, to determine the sensory characteristics of the products and their levels of acceptability, to determine the chemical composition of the different levels of the soy flour inclusion in meatballs, and to ascertain its cost effectiveness.

\section{MATERIALS AND METHODS}

Source of raw materials: The experiment was carried out in the Faculty of Agriculture laboratory, University of Benin, Benin City. The following materials were used: $2 \mathrm{~kg}$ beef was purchased from New Benin market. The connective tissues were trimmed off after which it was washed and stored in a deep freezer until when needed. $4 \mathrm{~kg}$ soybean was purchased from New Benin market, and processed into flour as described in Fig 1.

Experimental tr eatments: Five different combinations of soy flour/beef were investigated, each in three replications. The combinations were as follows; (i)

$0 / 100 \%$ soy flour/beef (control) (i) $15 / 85 \%$ soy flour/beef (iii) $20 / 80 \%$ soy flour/beef, and (iv) $25 / 75 \%$ soy flour/ beef.

Processing: The stored beef was thawed at room temperature $\left(26 \pm 2^{\circ} \mathrm{C}\right)$ and was ground using Monlinex meat mincer, Model ( $\mathrm{v} \mathrm{6).} \mathrm{The} \mathrm{soybean} \mathrm{(G} \mathrm{lycince} \mathrm{max)}$ was processed into soy flour as shown in Fig. 1

M ix formulation of soy meatball: The mix was produced as shown in Fig. 2, substituting meat with soy flour at $15 \%, 20 \%, 25 \%$ and $30 \%$ for beef. Whole beef was used as the control. Blue flame produced by a medium sized kerosene stove was used. The soy-meat mix formulation is shown in Table 1 . The soy-meat mix was manually rolled into small balls of $3 \mathrm{~cm}$ in diameter each (see Fig 2). In other to reduce bias, condiments were of equal proportions in the individual mix formulation resulting into $250 \mathrm{~g}$ per mix. They were then fried in hot vegetable oil using a deep fat fryer at $170^{\circ} \mathrm{C}$ (model PH-515) for 3 minutes. Each soy meatball on the average, weighed 3.11 $\mathrm{g}$ before frying and $2.622 \mathrm{~g}$ after frying. The number of balls produced per treatment is shown in Table 5 .

W eight loss and yield deter mination: The weight of soy meat-mix and fried balls were taken and weight loss (\%) was calculated as follows;

Weight loss $(\mathrm{g})=$ soy meat mix-fried soy meatballs

Weight loss $(\%)=\underline{\text { weight loss }} \times 100$

$$
\text { Soy meat mix }
$$

The yield was also calculated as follows;

Yield $(\%)=\underline{\text { weight of fried soy meatball } \times 100}$

Weight of soy meat mix

Proximate analysis: The fried samples were analyzed for moisture, ash, ether extract, protein and carbohydrate (NFE) as described by AOAC (1990). These experiments were carried out in three replicates.

Sensory evaluation: Five samples were coded and presented to a semi-trained sensory panel made up 20 judges to evaluate samples according to degree of likeness in respect to colour, taste, texture and overall acceptance. Water and cracker biscuits were served in between samples assessment to enable panelists rinse properly and neutralize carryover flavours in their mouth. Panelists were served in their separate locations far away from the sample cooking and preparation room and samples were coded to reduce bias. A 7-point hedonic scale having 7 (like extremely) as the highest score and 1 (dislike extremely) as the lowest score was used according to the procedure described by Watts et al (1989).

Statistical analysis: The data obtained from the study were analyzed using randomized complete block design (RCBD) and simple LSD test was used to determine which sample differed significantly from the other.

\section{RESULT AND DISCUSSION}

The results of effects of varying soy inclusion on weight loss and yield parameters are as shown (Table 2). There was a reduction in weight loss from $27.33 \%$ to $12.96 \%$ resulting to an increase in yield as the level of soy flour inclusion increased. Soy flour inclusion increased the cooking yield by an average value of $87.04 \%$. There were 
Table 1. Mix formulation of soy meatball.

\begin{tabular}{|c|c|c|c|c|c|c|c|}
\hline \multirow{3}{*}{ I ngr edients } & \multicolumn{7}{|c|}{ Treatments } \\
\hline & \multirow{2}{*}{$\begin{array}{c}\text { Levels of Soy } \\
\text { Flour/B eef }(\%)\end{array}$} & 1 & 2 & 3 & 4 & 5 & Total \\
\hline & & $0 / 100 \%$ & $10 / 90 \%$ & $15 / 85 \%$ & $20 / 80 \%$ & $25 / 75 \%$ & \\
\hline Soy flour & \multirow{2}{*}{80} & 0 & 20 & 30 & 40 & 50 & 90 \\
\hline Beef & & 200 & 180 & 170 & 160 & 150 & 710 \\
\hline Wheat flour & 6.36 & 15.9 & 15.9 & 15.9 & 15.9 & 15.9 & 79.5 \\
\hline Salt & 0.18 & 0.45 & 0.45 & 0.45 & 0.45 & 0.45 & 2.25 \\
\hline Water & 1 & 2.5 & 2.5 & 2.5 & 2.5 & 2.5 & 12.5 \\
\hline Red pepper & 0.4 & 1 & 1 & 1 & 1 & 1 & 5 \\
\hline Thyme & 0.12 & 0.3 & 0.3 & 0.3 & 0.3 & 0.3 & 1.5 \\
\hline Curry & 0.6 & 1.5 & 1.5 & 1.5 & 1.5 & 1.5 & 7.5 \\
\hline Ginger & 0.6 & 1.5 & 1.5 & 1.5 & 1.5 & 1.5 & 7.5 \\
\hline Onion & 3.0 & 7.5 & 7.5 & 7.5 & 7.5 & 7.5 & 37.5 \\
\hline Seasoning cube & 1.6 & 4 & 4 & 4 & 4 & 4 & 20 \\
\hline Cassava Starch & 5.14 & 12.85 & 12.85 & 12.85 & 12.85 & 12.85 & 64.25 \\
\hline Sugar & 1 & 2.5 & 2.5 & 2.5 & 2.5 & 2.5 & 12.5 \\
\hline Total & $100 \%$ & $250 \mathrm{~g}$ & $250 \mathrm{~g}$ & $250 \mathrm{~g}$ & $250 \mathrm{~g}$ & $250 \mathrm{~g}$ & $1000 \mathrm{~g}$ \\
\hline
\end{tabular}

Table 2. Weight loss and yield per ball.

\begin{tabular}{lcccccc}
\hline Samples & $\begin{array}{c}\text { Number of } \\
\text { balls per mix }\end{array}$ & $\begin{array}{c}\text { Weight before } \\
\text { frying }(\mathrm{g})\end{array}$ & $\begin{array}{c}\text { Weight after } \\
\text { frying }(\mathrm{g})\end{array}$ & $\begin{array}{c}\text { Weight loss } \\
(\mathrm{g})\end{array}$ & $\begin{array}{c}\text { W eight loss } \\
(\%)\end{array}$ & Y ield (\%) \\
\hline $0 \%$ & 64 & 3 & 2.18 & 0.82 & 27.33 & 72.67 \\
$10 \%$ & 80 & 3.07 & 2.58 & 0.49 & 15.96 & 84.04 \\
$15 \%$ & 85 & 3.13 & 2.66 & 0.47 & 15.02 & 84.98 \\
$20 \%$ & 91 & 3.15 & 2.69 & 0.46 & 14.60 & 85.40 \\
$25 \%$ & 102 & 3.2 & 3.00 & 0.2 & 6.25 & 93.75 \\
\hline
\end{tabular}

Note: the diameter of each meatball was $3 \mathrm{~cm}$

Table 3. Proximate analysis of the soy meatball.

\begin{tabular}{|c|c|c|c|c|c|}
\hline Soy meatball & M oisture (\%) & A sh (\%) & F at $(\%)$ & Protein (\%) & Car bohydrate $(\%)$ \\
\hline $0 \%$ & 35.81 & 1.833 & 12.33 & 38.33 & 11.70 \\
\hline $10 \%$ & 34.92 & 1.933 & 14.67 & 34.88 & 13.56 \\
\hline $15 \%$ & 27.23 & 1.967 & 19.00 & 33.28 & 18.40 \\
\hline $20 \%$ & 25.05 & 2.133 & 21.33 & 33.09 & 18.55 \\
\hline $25 \%$ & 15.76 & 2.333 & 29.33 & 27.56 & 25.01 \\
\hline \multicolumn{5}{|c|}{ able 4. Treatment means of sensory evaluation for fried soy meatballs. } & \\
\hline Fried soy meatball & Colour & \multicolumn{2}{|c|}{ T aste } & Texture & Over all acceptance \\
\hline $0 \%$ & $3.833^{\mathrm{d}}$ & \multicolumn{2}{|c|}{$6.383^{\mathrm{a}}$} & $6.150^{\mathrm{a}}$ & $6.3^{\mathrm{a}}$ \\
\hline $10 \%$ & $6.017^{\mathrm{b}}$ & \multicolumn{2}{|c|}{$6.100^{\mathrm{b}}$} & $5.560^{\mathrm{b}}$ & $6.233^{\mathrm{a}}$ \\
\hline $15 \%$ & $6.567^{\mathrm{a}}$ & \multicolumn{2}{|c|}{$5.883^{\mathrm{c}}$} & $5.350^{\mathrm{bc}}$ & $6.017^{\mathrm{a}}$ \\
\hline $20 \%$ & $5.550^{\mathrm{c}}$ & \multicolumn{2}{|c|}{$5.217^{\mathrm{d}}$} & $5.083^{\mathrm{cd}}$ & $5.367^{\mathrm{b}}$ \\
\hline $25 \%$ & $5.433^{\mathrm{c}}$ & \multicolumn{2}{|c|}{$5.100^{\mathrm{d}}$} & $4.950^{\mathrm{d}}$ & $5.200^{\mathrm{b}}$ \\
\hline SEM & 0.0453 & \multicolumn{2}{|c|}{0.0465} & 0.1000 & 0.1095 \\
\hline
\end{tabular}

Mean superscripted by the same alphabet within columns are not significant different $(\mathrm{P}<0.05)$, Each parameter is expressed as mean \pm SEM (Standard Errors of Means)

significant differences $(\mathrm{P}<0.05)$ between the weights of the soy meatball due to frying. This result suggests an inverse relationship between soy inclusion levels and weight loss. Cooking yield represents the retention of water and solutes during processing of food product (Lecomte et al 1993). Ray et al (1981) observed significant increase $(\mathrm{P}<0.05)$ in cooking yield up to $26 \%$ soy concentration in his study using ground beef. According 


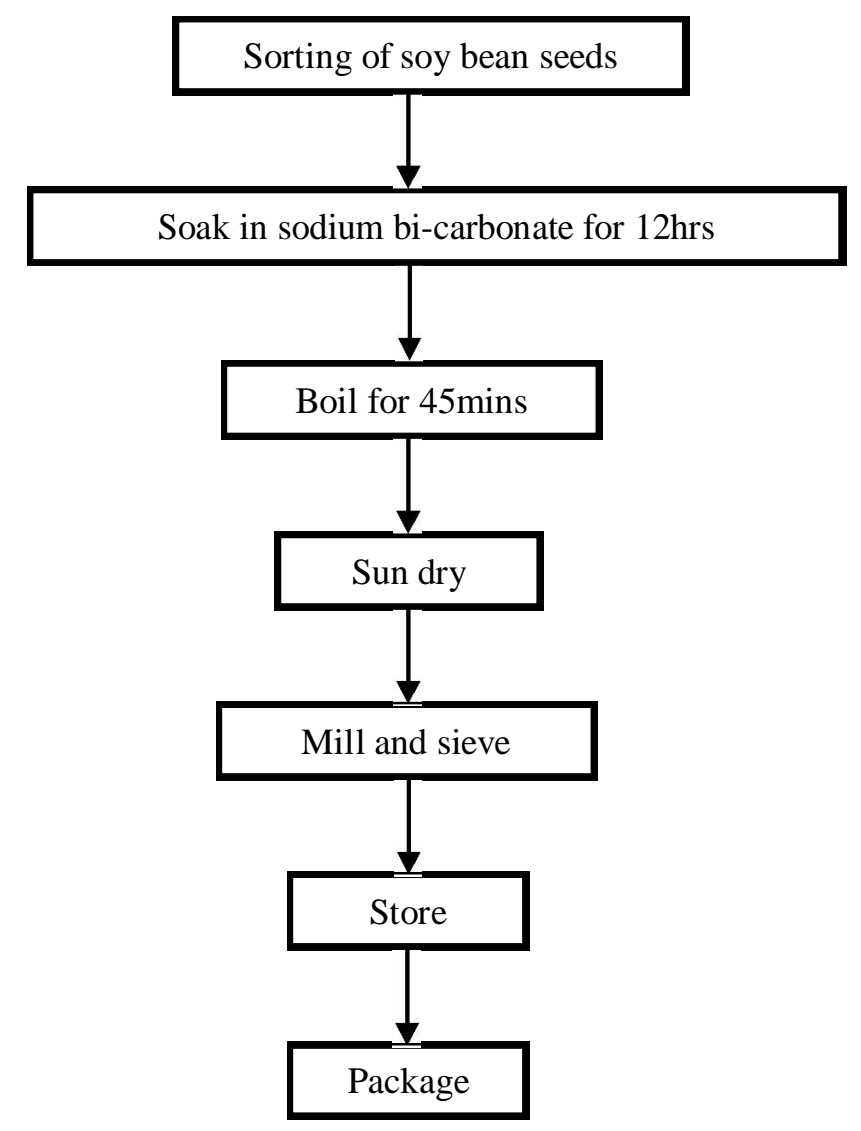

Fig. 1. Unit production of soy flour

to Scheiwger (1974), soy protein is commonly used in processed meat as a binder to reduce processing cost and increase yield. The trend in weight changes showed an increase in weight due to the increasing ability of the soy flour to bind moisture. This is consistent with the finding of Vaisey et al. (1975) that replacement of meat with legumes resulted in reduction drip losses. Soy protein contributes to the nutritional and general overall eating quality of meat products (Waggle et al., 1981). It has also been reported that preference of acceptance testing is often used to evaluate products reformed with soy ingredients and it is not common to find reports of reformulated products that are significantly preferred over the all meat control. The highest yield in this study is however lower than that of uncured and un spiced meat ball samples prepared in an earlier study (Igene et al., 2012), thus suggesting that there may be other factors which determine the yield of a sample. These range from length of thawing, frying, steaming and quantity of oil used.

Results of proximate analysis showed that $10 \%$ soy inclusion level yielded the highest protein level $(34.88 \%)$ with $25 \%$ inclusion level yielding the lowest $(27.56 \%)$. This suggests an inverse relationship between these parameters and thus requires further research. Increasing inclusion levels resulted in correspondingly higher fat content of the samples. The need to analyse the fatty acid profile of these samples is necessary to further elucidate the value of each sample as regarding the age groups of persons for which it is appropriate. There was no significant difference between the moisture content of the various combinations except the control ( $0 \%$ soy flour inclusion), which displayed the highest water holding capacity, while $25 \%$ soy flour inclusion was the poorest (Table 5).The estimate of ash in samples containing soy flour may be due to stored waste products in plants animals. It is known that plants do not have the ability to dispose of waste materials, instead they are stored as harmless materials in some parts of the plant which could be the seed, consequently the ash content of the full fat soy, flour is high. The fat emulsion at $0 \%$ soy flour inclusion being the lowest may have been due to fat drip during frying. This finding compares favourably with that of Igene et al. (2002). The increase in fat content may be attributed to the binding of free fat (fat absorption) by soy proteins (Wolf and Cowan, 1975; McWaters and Cherry, 1971; Roa et al., (1984). The clusion levels.

\begin{tabular}{lccccc}
\hline Ingr edients & $0 \%(\mathrm{~g})$ & $10 \%(\mathrm{~g})$ & $15 \%(\mathrm{~g})$ & $20 \%(\mathrm{~g})$ & $25 \%(\mathrm{~g})$ \\
\hline Soy flour & 0 & 5 & 10 & 15 & 20 \\
Beef & 200 & 180 & 160 & 140 & 120 \\
Whe at flour & 20 & 20 & 20 & 20 & 20 \\
Salt & 2 & 2 & 2 & 2 & 2 \\
Red pepper & 10 & 10 & 10 & 10 & 10 \\
Thyme & 10 & 10 & 10 & 10 & 10 \\
Curry & 10 & 10 & 10 & 10 & 10 \\
Ginger & 5 & 5 & 5 & 5 & 5 \\
Onion & 5 & 5 & 5 & 5 & 5 \\
Seasoning cube & 5 & 5 & 5 & 5 & 5 \\
Cassava Starch & 10 & 10 & 10 & 10 & 10 \\
Sugar & 2 & 2 & 2 & 2 & 2 \\
\hline Total am ount per mix $(\mathrm{N})$ & $\mathrm{N} 279$ & $\mathrm{~N} 264$ & $\mathrm{~N} 249$ & $\mathrm{~N} 234$ & $\mathrm{~A} 219$ \\
\hline
\end{tabular}




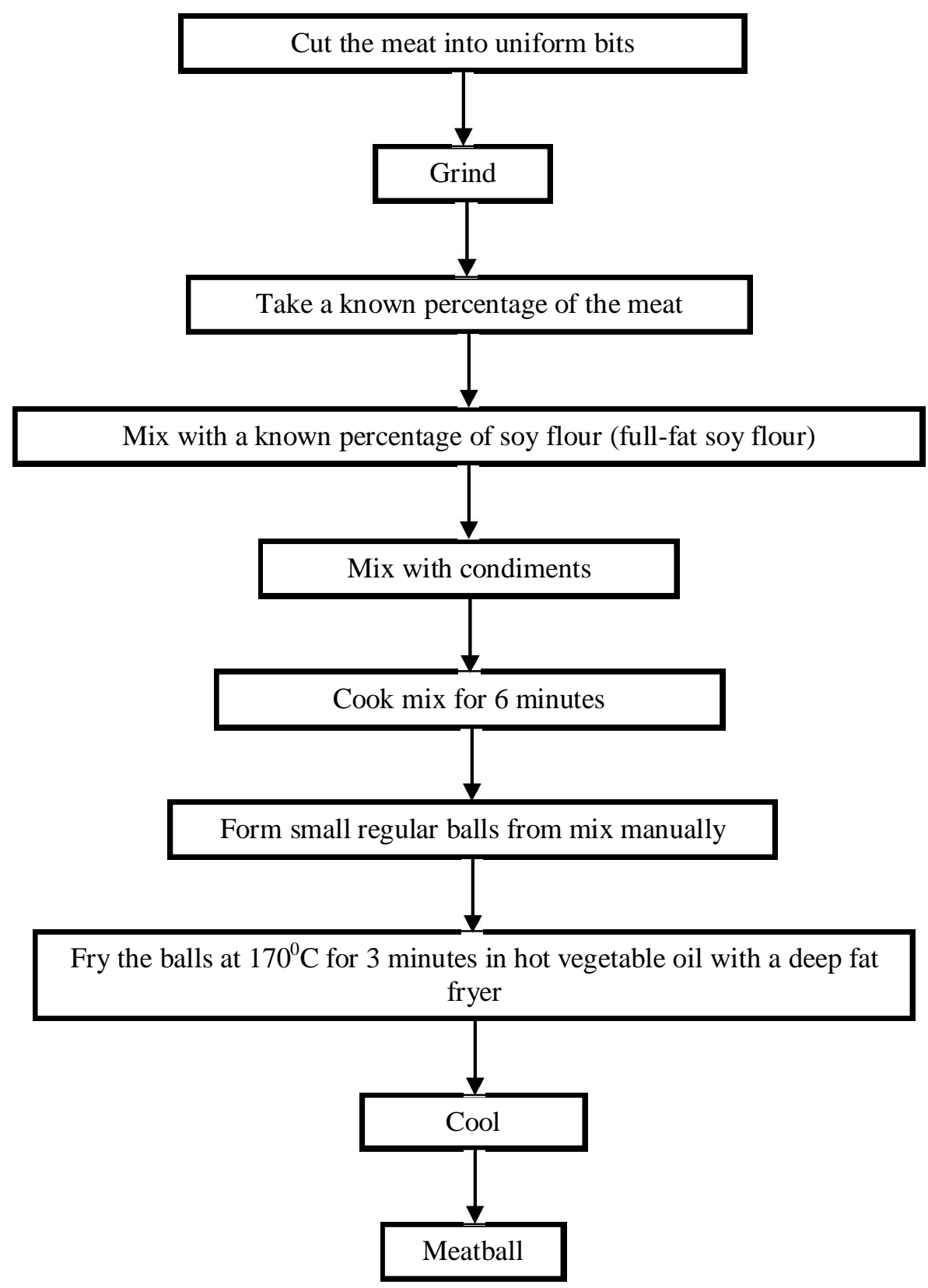

Fig. 2. Unit production of Soy meatball.

decrease in protein content is consistent with the work of Ray et al (1981) that as the soy level increased in ground meat, the protein decreased.

In the sensory evaluation, the colour scores were significantly different $(\mathrm{P}<0.05)$ at $0 \%$ to $15 \%$ except $20 \%$ and $25 \%$ which were not significantly different $(\mathrm{P}<0.05)$ from each other (Table 4). However, the value for colour at $0 \%$ soy flour inclusion was lowest while $15 \%$ was highest. In processing, colour has been identified as the single most important factor of meat products that influences consumer buying decision and affects their perception of the freshness of the product (Boles and Pegg, 2005). Generally, the taste decreased in the likeness for texture though there were no significant difference between $20 \%$ and $25 \%$ soy flour inclusion. $25 \%$ had the lowest texture score. The products were generally accepted. However, up to $15 \%$ soy flour inclusion was liked very much. This may indicate that soy flour inclusion up to $25 \%$ is acceptable. There were no significant differences between $0 \%, 10 \%$ and $15 \%$ soy flour inclusion in terms of overall acceptance. Up to $15 \%$ inclusion of soy flour in meatball formulation would therefore be most appropriate in the interim (Table 5).

Cost analysis of the various soy meatballs produced in this study showed that as soy flour inclusion increased the cost of production decreased (Table 5). At 10\% soy flour inclusion, there was a cost reduction of $\$ 15.00$, while at $25 \%$ there was a cost reduction of $\mathrm{N} 60.00$. On the average, there was a cost reduction of $\mathrm{N} 37.50$ at $\mathrm{N} 5.00$ per ball. This shows that the use of binders/extenders 
which are relatively cheap can culminate in economic production of these nutritious products for the eversoaring Nigerian population (Igene et al., 2012). These soy meatballs can therefore be recommended for inclusion into the diets of different categories of individuals based on health needs. They can also serve as convenience foods/snacks for the Nigerian consumers who have been earlier projected to buy more of pastries and other convenience foods to complement their busy lifestyles (DFM, 2007).

\section{Conclusion}

The study concluded that up to $25 \%$ soy flour inclusion was generally accepted by consumers. Amidst the soy flour inclusion, $10 \%$ and $15 \%$ were liked very much while $20 \%$ and $25 \%$ were moderately liked with respect to acceptability. It was obvious that the addition of soy flour helped in increasing the cooking yield by $87.04 \%$ on the average and reduction of production cost by N37.50 on the average when compared with the all meat product (control). Soy flour as an extender, increased the number of balls per mix from 64 balls (the control) to an average number of 89.5 balls (the soy meatballs). The analysis has therefore proven that the product can be accepted up to $25 \%$ soy flour inclusion as well as reducing production cost and increasing cooking yield. Since Nigeria has been blessed with abundant soybeans, incorporating soy protein products (its derivative) into meat and meat products will not only serve to reduce the cost of meat products, but will also act as a meat extender as well as lengthening its shelf-life. In view of the health benefits of soy, it is therefore important that advances in research and development of soy meat combination that has significant value in the fast food industry be made, especially in Nigeria and other developing countries where animal products supply is a major challenge.

\section{REFERENCES}

AOAC (1990). Official methods of analysis $15^{\text {th }}$ ed. W. Horwitz. (ed). Association of Official Analytical Chemists. Washington. DC.

Boles, J.A. and Pegg, R. (2005). Meat colour. Montana State University and Saskatchewan food product innovation programme, University of Saskatchewan.

DFM (2007). Initial public offering prospectus. Dangote Flour Mills A corporate document dated August 29, 2007.

FAO, (1991). Animal Production and Health; papers on guidelines of slaughtering, meat cutting and further processing. Food and Agriculture Organization, pp. 39 - 41.

Friedman, M. and Brandon, D. (2001). Nutritional and Health Benefits of Soy Proteins. J . Agric. F ood C hem; 49(3):10691086.

Igene, J.O., Akinjobi, K.S. and Evivie, S.E. (2012). Preliminary studies on the development of meatballs. J. Appl. Sci. \& Env. Manag. 16(2):167-170.
Igene, J.O., Oteku, I.T and Omorogieua, E (2006). Effect of Graded Level of Soyflour Inclusion on the Physical and Sensory Properties of Soy Chicken Burgers. J or mar 3(2):3848.

Igene, J. O. Oteku, T. I. and Akpata, J.A. (2002). Development of Hamburger using Full Fat Soybean Flour. Global J. of Agric Sci. 1(2):71-76

Iwe, M.O. (2003). The Science and Technology of Soybean. Rejoin Communication Services Ltd. Enugu, Nigeria pp. 258-259.

Kinsella, J.E. (1979). Functional Properties of Soy Proteins. J. Am. Oil chem. Soc., 56:242-246.

Lecomte, W.B., Zayas, J.F. and Kastner, C.C. (1993). Soy Protein Functional Sensory Characteristics Improved in Commercial Meat. J . F ood Sci. 58:466-472.

McWatters, K.H. and Cherry, J.P. (1971). Emulsification forming and protein solubility properties of defatted soy bean, peanut, field pea and pecan flour. J . F ood Sci. 45:14441450 .

Olomu, J.M. (2011). Monogastric Animal Nutrition. Principles and Practice $2^{\text {nd }}$ Edition. Jachem Publication, Benin City, Nigeria.

Raji, A.O. and Famurewa, A.V. (2008). Effect of hull on the physico-chemical properties of soy flour. Agric Eng Int; the CIGR Ejournal. Manuscript FP 07 018, vol X.

Ray, F.K. Parret, N.A., Vanstavern, B.D. and Ockerman, H.W. (1981). Effect of Soy Level and Storage Time on the Quality Characteristics of Ground Beef Patties. J. Food Sci. 46:1 162-1164

Roa, L.O., Droughon. F.A. and Molton, C.C. (1984) sensory character of thiringer sausage extended with soy protein. J Food Sci 49:334-336

Russell, T.A. (2004). Comparison of sensory properties of whey and soy protein concentrates and isolates. Food Science, vol. Master of Science (p. 132). North Carolina State University. North Carolina State USA.

Sacks, Lichtenstein, A., Van Horn, L. Harris W., Kris-Etherton, P., Winston, M. (2006). American Heart Association Nutrition Committee. "Soy Protein Isoflavones and Cardiovascular Health".

Scheiwger. R.G. (1974). Soy protein concentrate and isolate in comminuted meat system. J. Am Oil Chem Soc. 51:192A194A.

Vaisey, M., Tassor, L., McDonald, B.E. and Young, O.G. (1975). Performance of Fababean and Field Pea Protein Concentrates as Ground Beef Extenders. Can inst. Food Sci. techno. 8:74

Waggle, D.H., Decker, C.D. and Kolar, C.W. (1981). Soy products in meat, poultry and sea food. J. Am. O il Chem Soc. 20:341-342

Watts, B.M., Yimaki, G.L., Jeffery, L.E., Elias, L.G. (1989). Basic Sensory Methods for food Evaluation. Copyright International Development Research Centre. pp. 20

WHF (2004). Soyabean internal: file:11f://New Folder \the World's Healthiest Foods. The World's Healthiest Foods. Htm. pp. 1-16.

Wolf, W.J. and Cowan, J.C. (1975) Soybean as food source. Boca Raton. FL: CRC Press. Pp 45-80 